NBER WORKING PAPER SERIES

\title{
WELFARE REFORM AND CHANGES IN THE ECONOMIC WELL-BEING OF CHILDREN
}

\author{
Neil G. Bennett \\ Hsien-Hen Lu \\ Younghwan Song \\ Working Paper 9399 \\ http://www.nber.org/papers/w9399 \\ NATIONAL BUREAU OF ECONOMIC RESEARCH \\ 1050 Massachusetts Avenue \\ Cambridge, MA 02138 \\ December 2002
}

The authors would like to thank Larry Aber, Rebecca Blank, Steve Cameron, Maria Cancian, Sheldon Danziger, Greg Duncan, Robert Kaestner, Sanders Korenman, Mary Clare Lennon, Daniel Lichter, Robert Moffitt, June O'Neill, Tim Smeeding, Seymour Spilerman, and Jane Waldfogel for their helpful comments and suggestions. However, the conclusions reached and any errors are the sole responsibility of the authors. Previous versions of this paper were prepared for presentation at the 2002 meetings of the American Sociological Association and the 2001 meetings of the Population Association of America. This paper was written, in part, while Bennett was also Senior Advisor to NCCP for Demographic Research and Analysis. The views expressed herein are those of the authors and not necessarily those of the National Bureau of Economic Research.

(C) 2002 by Neil G. Bennett, Hsien-Hen Lu, and Younghwan Song. All rights reserved. Short sections of text not to exceed two paragraphs, may be quoted without explicit permission provided that full credit including, (C) notice, is given to the source. 
Welfare Reform and Changes in the Economic Well-Being of Children

Neil G. Bennett, Hsien-Hen Lu, and Younghwan Song

NBER Working Paper No. 9399

December 2002

JEL No. I3

\begin{abstract}
$\underline{\text { ABSTRACT }}$
Since the implementation of the Temporary Assistance for Needy Families program in late1996, welfare rolls have declined by more than half. This paper explores whether improvements in the economic well-being of children have accompanied this dramatic reduction in welfare participation. Further, we examine the degree to which the success or failure of welfare reform has been shared equally among families of varying educational background.

We analyze data from the March Current Population Surveys over the years 1988 through 2001. Specifically, we link data for families with children who are interviewed in adjacent years and determine whether their economic circumstances either improved or deteriorated. We use two alternative approaches to address this general issue: a variety of regression models and a differencein-differences methodology. These approaches provide consistent answers. In a bivariate framework TANF is associated with higher incomes; but this association becomes insignificant in the presence of business cycle controls. We also determine that children who were poor at an initial time period benefit differently, depending on their parents' educational attainment level. Poor children with parents who do not have a high school degree are significantly worse off in the TANF era, relative to the era prior to welfare reform, than are their more educated counterparts.
\end{abstract}

Neil G. Bennett

Baruch School of Public Affairs and CUNY Graduate Center 17 Lexington Avenue

Box C-412

New York, NY 10010

and NBER

neil_bennett@baruch.cuny.edu
Hsien-Hen Lu

National Center for

Children in Poverty

154 Haven Avenue

New York, NY 10032

h1641@columbia.edu
Younghwan Song

Union College

Department of Economics

Social Sciences Building

Schenectady, NY 12308

songy@union.edu 


\section{Introduction}

Since state waivers to federal welfare regulations were first implemented in the early 1990s and with the passage of the Personal Responsibility and Work Opportunity

Reconciliation Act of 1996 (PRWORA), both state and federal governments have increased efforts to reform the welfare system. A major goal of welfare reform has been to reduce dependency on public assistance, but there was no explicit attention paid to improving the economic well-being of poor families. PRWORA does, however, establish as a goal that child poverty not significantly increase.

There has been much discussion - in the media, among policymakers, and in academia - of the extent to which welfare reform has achieved these objectives. With the fifth anniversary of PRWORA in 2001 and the coming reauthorization of the law in 2002, it is an opportune moment to examine the changes in the economic well-being of children that have taken place during the Temporary Assistance for Needy Families (TANF) era - the assistance program created under PRWORA.

The major finding of this study is that the changes in the economic well-being of poor children that have occurred as we have transitioned into the TANF era are strongly differentiated by the educational attainment of their parents. All poor families have not experienced this reform effort in the same way. In particular, the family incomes of poor children with less-educated parents have suffered greatly in the TANF era, relative to the era prior to any welfare reform, while the family incomes of children from college-educated families have improved.

If the goal has been simply to reduce the welfare rolls, then there is no doubt that welfare reform has notably met that goal. As seen in Figure 1, since the enactment of the new welfare law in August 1996, national welfare caseloads have declined dramatically, by more than one-half (56 percent) - from 12,241,000 recipients in August 1996 to 5,343,000 recipients in September 2001. Reductions in caseload varied substantially across states, 
ranging from under one-third in five states - including Indiana (11 percent), Rhode Island and North Dakota (29 percent), and Minnesota and Nevada (32 percent) - to over three-quarters in three states - Wyoming (92 percent), Idaho (90 percent), and Florida (77 percent). Caseloads peaked in 1994, when the average monthly number of recipients was $14,226,000$, constituting 5.5 percent of the U.S. population. By September 2001, that proportion had been reduced to 1.9 percent. $^{1}$

Conventional wisdom would have that TANF has had several beneficial consequences. Primus (2001) notes, for example, that the poorest 40 percent of single mother families increased their earnings substantially between 1995 and 1999 (after adjusting for inflation). Further, he cites reductions in child poverty as a positive outcome of welfare reform. Such a belief arises from positively correlated trends in poverty and welfare caseload since the implementation of TANF. Figure 2 shows that a decline in the child poverty rate from 19.6 percent to 15.4 percent between 1996 and 2000 has accompanied the dramatic lowering of the welfare rolls, from 12.6 million in 1996 to 5.8 million in 2000 . Two questions must be addressed, however, before we may declare welfare reform to be the success many believe it to be. First, can the observed decline in poverty be attributed directly to the implementation of the TANF program, and second, has TANF been associated with universally improved incomes?

Despite long-standing interest in the policy, academic, and foundation communities, research conducted on the consequences of national welfare reform for the actual economic well-being of families, and of children, in particular, has only now begun to be released. Studies that move beyond computing the reductions in caseload often either focus on specific states or rely on nationally-representative data that refer to a period of time associated with welfare reform in its infancy.

\footnotetext{
${ }^{1}$ All welfare caseload statistics available at http://www.acf.dhhs.gov/news/stats/newstat2.shtml.
} 
Using data from the March 1988 through March 2001 Current Population Surveys, conducted by the United States Census Bureau, in this paper we adopt a national perspective, rather than the more localized approaches taken by some others before us. In particular, using these nationally-representative survey data, we study the association between a variety of factors, including the implementation of TANF, and changes in the economic well-being of families with children from one year to the following year. Specifically, we examine the link between the TANF era environment and a family's logged income-to-needs ratio. ${ }^{2}$ However, more than assessing the overall association between TANF and the income of poor families, we seek to determine the importance of educational attainment in that relationship. Given that individuals with less education bring fewer skills to the labor market, it is possible that they will meet with more limited success in the harsher environment associated with TANF than they did in the years preceding welfare reform (i.e., before either TANF or state waivers). Our analyses test whether this hypothesis is borne out in the data.

Although PRWORA was passed in 1996, we study changes in income since 1987. By covering this more extensive period, we are able to compare trends before and after the 1996 PRWORA. Specifically, we in effect compare patterns in the TANF era with those in the period prior to the implementation of any state waivers. As detailed in Table A1, waivers were implemented by 32 states over a four year or so time frame, first in Minnesota and New Jersey (October 1992) and last in Hawaii (February 1997).

We control for states' implementation of welfare reform in the form of waivers prior to 1996, but we do not seek to estimate the changes in economic well-being associated with state waiver programs. Rather, we simply control for state waivers in our models for the period in which they were in effect.

\footnotetext{
${ }^{2}$ The income-to-needs ratio is defined as a family's income divided by the poverty threshold associated with that family's size and structure. For example, if a family had an income of $\$ 13,500$ and the poverty threshold for this family were $\$ 18,000$, then its income-to-needs ratio would be 0.75 (or 75 percent). (The poverty threshold for a family of four in 2001 was $\$ 18,267$.)
} 
We are able to adopt a panel-study approach in our analysis due to the fact that a subsample in any given March Current Population Survey is interviewed again in the following year's March survey. Thus we can track individuals over a two-wave (one-year) period. In this study we determine changes in the economic well-being of children associated with the implementation of TANF in 1996. Our variable of interest is the logged income-to-needs ratio of the families in which these children reside. ${ }^{3}$ This series of one-year windows of panel data include samples of individuals who are at various stages of duration of poverty, employment/unemployment, welfare use, or post-welfare use and whose data are collected over a wide range of calendar years.

\section{Past Research}

Many in the political arena and among the media have measured the success of welfare reform in terms of the extent to which welfare rolls had been reduced. This measure is insufficient to the task: Large numbers of individuals may leave the rolls, but one important element of the program's success is whether individuals who are poor or receiving public assistance at an initial time period are economically better off (or at least no worse off) in a subsequent time period as a result of TANF.

One nationally-representative data set that has been analyzed to address this issue is the National Survey of American Families (NSAF). Researchers have been able thus far to exploit data from the first wave of the NSAF, which was conducted in 1997. Two studies, in particular, merit attention.

Loprest (1999) examines some of the economic outcomes of those who left welfare in the early period following reform. She found that the "majority of welfare leavers left because of work" and that their "hourly wages, monthly earnings, and job characteristics all

\footnotetext{
${ }^{3}$ Using simply the income-to-needs ratio at time $t$ as our variable of interest yields results that are qualitatively identical to those obtained using the logged ratio.
} 
indicate that leavers are entering the low end of the labor market." Garrett and Holahan (2000), on the other hand, focus upon changes in health insurance coverage. They find, for example, that as many as 49 percent of women and 30 percent of children were uninsured after one year or more subsequent to leaving welfare. A considerable drawback of the NSAF studies is that the survey, having been fielded in 1997, uses 1996 - an extremely early stage of welfare reform - as its reference year for assessing poverty. Data collected in 1999 have recently been released, but the cross-sectional nature of the data render causal inference difficult.

Another study worth noting is that by Cancian, Haveman, Kaplan, and Wolfe (1999), who focus exclusively on the situation in Wisconsin. Although the geographic scope of the study is limited, it provides excellent insight into the dynamics of economic well-being following departure from the welfare rolls in Wisconsin. Among other things, they find that the increase in earnings among leavers fell short of fully compensating for foregone welfare benefits. Almost two-thirds of leavers ended up with total incomes less than when they were participating in AFDC. In a more recent study of the Wisconsin data, Cancian, Haveman, Meyer, and Wolfe (2000) found that individuals who left welfare under the relatively strict rules of the TANF program experienced lower earnings than did those who left in the earlier time of less stringent rules associated with Wisconsin's waivers. This is consistent, the authors state, with the notion that TANF forces off the rolls people who bring fewer employment skills to the labor market.

Several papers rely on data from the Current Population Surveys (CPS) conducted by the Census Bureau. Moffitt (1999) analyzes the effects of state waivers by examining data on women aged 16 through 54 from the March CPS for the years 1977 through 1995 and the outgoing rotation groups from the CPS, as well. He reports the following results: (a) among the least educated women (those without a high school degree), waivers had no discernable 
effect on earnings, wages, or family income, although they did decrease AFDC participation and increase weeks and hours worked, and (b) among better educated women (i.e., those with a high school degree and no more), waivers were associated with higher earnings, in addition to increased hours worked.

Connolly (2000), too, focuses on the effects of waivers, using March CPS data from 1994 through 1996. Utilizing a difference-in-differences approach, she finds that (a) with minor exceptions, work-related waivers did not increase the earnings of welfare recipients relative to non-recipients, (b) waivers often had a small negative effect on the income of welfare recipients, and (c) waivers appeared to depress earnings less among rural, than among urban, welfare recipients.

Last, Schoeni and Blank (2000) analyze data on women aged 16 through 54 from the March CPS for the years 1977 through 1999. They conclude the following: (a) Among the least-educated women (those without a high school degree), waivers decreased welfare participation and increased weeks and hours worked. In contrast to Moffitt, however, total family income was determined to rise in response to waivers. No significant effects were found among better-educated women (those with more than a high school degree); (b) TANF appeared to have twice the effect of waivers on welfare participation among those who did not complete high school. However, among all people TANF showed no significant effect on the proportion working, weeks or hours worked, or on individual or family earnings.

Various researchers have concluded that it is important to judge the influence of welfare reform on the income of families with children and to identify particular categories of people who have been affected by welfare reform either to their benefit or detriment (Blank 2002, and Lichter and Jensen 2000). Along these lines, then, our objective is to address the key monitoring questions of interest, as presented in a recent report issued by the National Research Council (Moffitt and Ver Ploeg 2001): "How has the well-being of the 
low-income population and key subgroups evolved subsequent to welfare reform? Which subgroups are doing well and which are doing less well? Which subgroups are in greatest need and deserve the attention of policy makers?"

In this paper we analyze data from the March CPS, for each year from 1988 through 2001. Because most relevant income data from the CPS refer to the year prior to that in which the data were collected, our time frame of analysis ranges from 1987 through 2000. In this paper we examine two major issues:

- What changes in the economic well-being of children have accompanied the implementation of TANF? And,

- To what extent do these changes in income depend on a parent's level of educational attainment?

We hypothesize, in particular, that it is children in poor families with the least educated parents who have fared worst in the TANF era. These parents are likely to have the most difficulty in becoming economically successful in the harsher environment accompanying welfare reform.

This paper is distinguished from previous research efforts in several ways. First, we focus on the economic well-being of children under 18 years of age, rather than that of adults. Second, as we describe below, linking adjacent years of the Current Population Survey enables us to adopt a panel perspective in our analyses. Thus, with appropriate controls for selective attrition, we can track individuals from one year to the next. Third, our analyses are based on data through the March 2001 implementation of the Current Population Survey. As a consequence, we have several years of post-PRWORA data to judge the changes occurring in the era of welfare reform. Due to data limitations, most previous studies have been devoted exclusively either to the impact of state waivers on economic well-being or to the effects of TANF in its relative infancy. It has been noted (Blank 2002) that although 
econometric models such as ours are not able to focus on the impact of various specific components of the TANF program, they are likely to be fruitful in yielding estimates of the overall effects of welfare reform.

\section{Data and Methods}

\section{Sample}

The Current Population Survey, conducted by the U. S. Census Bureau, is a monthly survey of about 50,000 households representing the civilian noninstitutional population of the United States. It has been the most commonly used source of data on income and employment due to its sample being large and nationally representative. The CPS questionnaire has a basic component associated primarily with labor force participation and employment and a supplemental section that is repeated the same month each year. The March Survey includes the Annual Demographic Supplement, which provides comprehensive information on work experience, income, and noncash benefits received in the preceding calendar year.

Even though the CPS is a cross-sectional survey, its 4-8-4 sampling rotation scheme allows the construction of a series of panel data with each panel consisting of an initial observation and repeated observation separated by a one-year interval. Each month there are eight rotation groups in the survey. A new rotation group enters the survey every month and is interviewed for four consecutive months, temporarily out for eight consecutive months, and then re-interviewed for four consecutive months before they are finally dropped from the survey. Because the second set of four interviews occurs in the same calendar months as the first set of four, respondents can be linked across two adjacent years. Theoretically, with no attrition, half of those interviewed in March of one year could be matched to those interviewed in March of the following year. Previous studies, such as those by Moffitt (1999), 
Connolly (2000), and Schoeni and Blank (2000) have modeled a time series of Current Population Survey data, but from a cross-sectional perspective, rather than matching individuals in adjacent years.

The sample used in our analysis consists of families with children under 18 with at least one parent from the matched sample of the 1988 through 2001 March CPS files. The CPS files have a hierarchical structure, in which household records precede family records and person records. Consequently, after matching households, individuals within these matched households can be linked. Among the March CPS data in the years between 1988 and 2001, one pair of years, 1995-1996, cannot be matched. That is the period during which the sampling frame transitioned from being based on the 1980 Census sample design to that of the 1990 Census.

The March CPS files from adjacent years were matched using three steps of an algorithm described in Welch (1993). Due to attrition, fewer than the expected one-half of the households in one survey could be successfully matched to the households in the survey in the following year and also not everyone within the matched households could be matched. Among 223,467 children under 18 with at least one parent in the theoretically matchable onehalf of the households, 150,046 children (67.1 percent) are matched in the sample. This proportion of matches is similar to that found in other studies (Katz, Teuter, and Sidel 1984, and Madrian and Lefgren 1999).

\section{Missing Data Problems}

The fact that one-half of the respondents in each CPS are not interviewed in the subsequent CPS does not introduce bias in any statistical analysis of the remaining one-half of the initial sample. The nonexistence of one-half of the time 1 sample at time 2 is simply a product of the sample design. However, the absence of one-third of the potential sample of 
children under 18 - that is, those who theoretically could be matched - and the likely nonrandom selection of the matched sample (Peracchi and Welch 1995) requires us to address such selection appropriately. We must determine that those who could be matched were no different from those who could not or, alternatively, we must adequately address any differences between the matched and unmatched series of data so as to insure that these differences do not bias our conclusions.

We use multiple imputation (Rubin 1987, Schafer 1997) to solve this missing data problem caused by cases that were eligible to be, but could not be, matched across adjacent years. The bootstrap multiple imputation approach used in this study does not impose an assumption for the functional form of the mechanism that dictates whether data are missing. It is, then, more robust than a method, such as a selection model, which does make such an assumption. Moreover, while multiple imputation essentially puts new data in the place of missing data, it does not alter the original observed data (that were not missing). The large sample size of this study also helps to improve the performance of multiple imputation (Schafer 1997). After multiple imputation, only nine percent $(19,953$ / 223,467) of the cases do not have either observed or imputed time two values. This method is discussed in some detail in the Appendix.

Our approach is first to present estimates obtained from ordinary least squares models that use only the matched sample. Then, we compare those findings with those we derive from the multiple imputation procedure. In order to ensure the robustness of multiple imputation results, the final models reported in this study are also compared with selection models based on maximum likelihood estimation procedures (Heckman 1979, Nawata and Nagase 1996) and with conclusions drawn from a difference-in-difference perspective described below. In our analyses, we have confirmed that the findings obtained from all four approaches are consistent with one another. 
Examining Table 1, we find that the biases introduced in the observed sample are as would be expected. For example, the average income-to-needs ratio of young parents, that is, age 20 or under, whom we were not able to match, was lower than the ratio among parents whom we successfully matched. The income-to-needs ratio among matched young parents in our sample was .83 , whereas the ratio was considerably lower -.76 - for the joint sample that was matched and imputed. Similarly, we see that the income-to-needs ratio of those without a high school degree in our sample and who were matched was .75 , while the ratio was .68 for the sample of both matched and imputed individuals who did not graduate high school.

While it is true that unmatched individuals differ significantly from matched individuals when we examine each variable singly (such as income, education, single parenthood, etc.), the difference in each variable is apparently almost fully accounted for by the other variables included simultaneously in the model.

Waivers, of course, varied considerably by state with respect to when they were implemented. TANF, although put into law nationally at a single time, also varied in the states' dates of implementation. Thus, to discern the relationship between TANF and income, we must first know the implementation dates for each state. Again, although we do not examine in any detail the link between state waivers and income, we control for any waiver effects by incorporating a variable in all our models that accounts for the date at which each state waiver was implemented. The dates we used as a basis for our analysis were obtained from the ASPE web site and appear in Table A1.

\section{Observed Trends in Poverty and Income-to-Needs Ratios}

Before we engage in any modeling, it is instructive to examine the raw CPS data for patterns and trends in income over time. We do so in Figures $3 a$ through $3 c$, which offer 
provocative descriptions of these differentials and changes in the income-to-needs ratio. In Figure $3 a$ we see that, in the recent era of welfare reform, income-to-needs ratios among those who were poor at time 1 declined on average over time. However, when we disaggregate this information by poverty status at time 2 , we find that income decreased over time only among individuals classified poor at time 2 and actually increased among those who escaped poverty at time 2 .

To whom specifically does this result apply? That is, do people of all educational attainment levels and who were poor at the second time period experience similar declines on income? Do all of those lifted out of poverty at time 2 - irrespective of educational achievement - find their incomes increasing in the welfare reform era?

Figure $3 b$ shows that, among these better off individuals, patterns in income-to-needs ratios, classified by educational attainment levels, are substantially the same. Although income levels, obviously, are strongly related to education, no subgroup is subject to a very different pattern over time than the others.

That is not the case, however, among people who remained poor in the second time period. It is reasonably clear from Figure $3 c$ that the subgroup of people who did not graduate college has done increasingly worse over time in the era of welfare reform.

\section{Analytic Strategy}

In our effort to explore the association between the economic well-being of children and the eras on which we focus, we adopt an approach that considers TANF a "treatment." To judge this relationship, we estimate an analysis of covariance model that can be represented as follows (Winship and Morgan 1999):

$$
Y_{i, t}=\alpha+Y_{i, t-1} \gamma+C_{i, t-1} \delta+W_{i, t} \lambda+T_{i, t} \beta+u_{i, t}
$$


where, in this instance, $Y_{i, t}$ is the logged income-to-needs ratio for individual $i$ at time $t, Y_{i, t-1}$ is that ratio at time $t-1, \mathrm{C}_{\mathrm{i}, \mathrm{t}-1}$ is our set of relevant covariates measured at time $\mathrm{t}-1$, and $\mathrm{T}_{\mathrm{i}, \mathrm{t}}$ is the so-called "treatment," TANF. The TANF variable is time-varying and assumes the value of one at the time of TANF implementation and each year thereafter. Prior to implementation, the value is given as zero. ${ }^{4}$ Thus, $\beta$ describes the association between the TANF environment and child economic well-being, net of other, perhaps confounding, factors. $W_{i, t}$ is another time-varying variable for state waiver policies that was coded by using a strategy similar to the one described above for coding the TANF implementation. If $T_{i, t}$ is coded as one, $W_{i, t}$ is coded as zero. $\mathrm{W}_{\mathrm{i}, \mathrm{t}}$ is included as a control variable so that our TANF coefficient is based on a comparison of cases not experiencing any reform with cases experiencing the full implementation of TANF. This model may be estimated by OLS (Winship and Morgan 1999). We should reiterate here that the estimates we obtain are "average treatment effects," that is, the effect of TANF averaged over several calendar years and durations of welfare use. One should also note that in our analyses we treat all children from the same family as a cluster.

Our overall analytic strategy is first to estimate the above model by using the simplest means available, OLS. Subsequently, in order to address rigorously the shortcomings in the data, we estimate an OLS model with multiple imputation and a selection model with maximum-likelihood estimation, and then judge the extent to which these first findings are modified.

In order to further examine the robustness of our estimates using model (1) described above, we also assess the link between policy and economic well-being by invoking the widely used difference-in-differences method (see, e.g., Meyer 1995, Connolly 2000, Schoeni and

\footnotetext{
${ }^{4}$ Note that in all models, we include a similar variable for state waivers and, when appropriate, various related interaction terms in order to control for their effects. Due to the fact that state waivers are not of direct interest in this article, we do not present the variables' coefficients. The state waiver variable is dichotomous and time-varying, "switching on" at the time a state implements its waiver program. By adding state waivers to the models, we are controlling for those earlier effects.
} 
Blank 2000, Moffit and Ver Ploeg 2001, and Ellwood, 2001). In the application of the difference-in-differences method, we use children living in families above 300 percent of poverty line as the control group - that is, a group who would not likely be affected significantly by welfare reform - and those living in families below 100 percent of poverty as the treatment group. We expect a robust result of model (1) to be consistent with the results obtained by using the difference-in-differences method and vice versa.

If we achieve from these varied approaches results that are consistent with one another, then we will estimate the percentage change in income associated with welfare reform for individuals in various educational attainment categories.

\section{Discussion of Findings}

\section{OLS Analyses}

We initially adopt a basic OLS framework, in order to estimate baseline results that do not rely on the imputation of data. Our objective is to estimate the relationship between states' transitions to TANF on the income-to-needs ratios of the families in which children reside. We build the model in increments in order to understand properly the mechanisms underlying the determination of income at the second time period. As discussed above, current thinking is that TANF has had a beneficial influence on economic well-being, as reflected in the recent decline in aggregate poverty rates.

In Table 2a we present the coefficients and associated standard errors from both restricted and full models predicting logged income-to-needs ratios at the second time period. We build our model incrementally to explore how economic well-being - as represented by income-to-needs ratios - has changed with the TANF era and an assortment of other factors. 
Model 1 of Table $2 \mathrm{a}$ is the simplest of our models, in which only TANF is used to predict the income-to-needs ratio of a child's family at the second time observation. The significant positive coefficient is consistent with the fact that poverty rates declined over the period from the inception of TANF - which ranged from October 1996 to January 1998, depending upon the state - through 2000. However, when we include yearly dummies, as seen in Model 2 of Table 2a, the positive relationship between TANF and income is rendered insignificant. Consequently, we may infer that it was not the TANF program that lifted incomes after 1996; rather, the economic improvements stemmed from the effects of the business cycle, independent of the implementation of TANF.

In Model 3, we build on the previous model by including a variable indicating whether an individual was poor at the first time period and the interaction between this variable and the TANF implementation variable. In this fashion, we can focus on the TANF environment for just those who are initially poor. Indeed, when we include this interaction term, we find that the TANF environment is of no consequence generally, but is a significantly negative one among poor individuals. That is, it appears that those who are initially poor are considerably more likely in the TANF era than in the era prior to state waivers to earn lower incomes in the following year. Thus, poor families experienced diminished economic well-being as they moved from one year to the next during the TANF era, compared to during the pre-reform environment.

Finally, we add a variety of variables to our model that theoretically and/or logically might affect one's likelihood of being poor. These are: ${ }^{5}$

- Race/Ethnicity: Black, Hispanic, Other (white non-Hispanic omitted)

- Age of child

- Age of parent: 21-30, 31 or older (under 21 omitted)

\footnotetext{
${ }^{5}$ In our analyses, we also examined whether the status of public assistance at time one, a time trend in marital status (cf. Bumpass and Lu, 2000), state-time interaction dummies, a term representing the interaction between single motherhood and TANF, a term representing the interaction between single motherhood and TANF, and age cohort by welfare policy era interactions substantively altered our conclusions. They did not.
} 
- Non-rural

- Family structure: Mother only, Father only (both parents omitted)

- Parental marital status: Never married, divorced-separated-widowed (currently married omitted)

- Number of children

- Family size

- Parent employed at first time period

- Log of income-to-needs ratio at first time period

- State unemployment rate

- Education: Less than high school, some college, at least a college degree (exactly a high school degree omitted)

- Each education category interacted with being poor at first time period

In the full model shown in Table 2a (Model 4), we include this set of background variables, most of which are individually-based. However, one may note that we also include certain macro "contextual" variables in order to control for a variety of overarching effects that would have an impact on all individuals. These macro variables consist of the state unemployment rate as well as state and year dummies (the coefficients of which are not exhibited) and their interactions. In this way, we net out the effects of national and state patterns and trends in the business cycle on an individual's economic well-being. It is important, as well, to control for state unemployment levels because unemployment rates tended to be higher in states in which welfare reform was instituted relatively early in the form of waivers as compared with states in which it was not (Schoeni and Blank 2000).

In all, then, we control for possibly confounding effects that many variables not part of our focus may bring to bear on estimating the true association between the TANF era and income at the second time period. Thus, we can estimate the strength of the link between TANF and income, net, for example, of the obviously important influence of state and national business cycles.

The major purpose of Model 4 is not only to see if the relationships implied by Model 3 hold up in the presence of an array of control variables, but also to examine how the link between the TANF era and an individual's economic well-being is differentiated across 
educational attainment levels. Thus, we include interaction terms between "TANF" and each educational category.

All of the background variables behave much as expected. Controlling for the (logged) income-to-needs ratio and employment status at the first time period, minority, less educated, and rural parents, for example, have significantly lower income-to-needs ratios at the second time period than their white, better-educated, and urban counterparts. Regarding parental age, it appears that young parents - that is, under 21 years of age - have higher incomes than older parents do (net of all other factors). The youngest parents are those whose poverty status is likely to be affected beneficially from one year to the next, as they are more likely to profit from job training and work experience. ${ }^{6}$

Shifting our focus to the variables of interest, we see that the main TANF coefficient remains insignificant. The picture regarding the TANF era is somewhat more complicated, however, than its main coefficient would suggest. In particular, the apparent significance of the TANF era among poor individuals has disappeared.

Individuals with less education possess fewer of the skills necessary to succeed in the labor market. Cancian et al. (2000) have shown that, in Wisconsin, more educated welfare recipients do considerably better than less educated recipients on several indicators of "success." Thus, we further examine in Table $2 \mathrm{a}$ - as shown in Model 4 - how the education of parents modifies the relationship between TANF and the economic well-being of their children. Children of parents without at least some college are at a distinct disadvantage. This group of children does not experience the significant improvement in income-to-needs ratios in the presence of TANF that their counterparts with better educated parents do. Such a disadvantage is imposed on all children with less educated parents and not only on those

\footnotetext{
${ }^{6}$ Parental age is a proxy for the parental life-course earnings profile that may reflect both parental work experience and the labor force participation of married mothers subsequent to the birth of their child(ren). We suspect the nonlinear pattern for parental age is a combination of these two elements and merits further analysis in a later study.
} 
who are poor. On top of that effect, however, is a large negative impact of the income-toneeds ratios among poor children with parents who never obtained a high school degree. As seen in the large negative coefficient $(-0.298)$, this group is singled out for particularly dim economic prospects in the TANF era.

The results based on OLS modeling with selection and with multiple imputation that correspond to Model 4 of Table $2 \mathrm{a}$ are presented in Table $2 \mathrm{~b}$. We show that the selection effects due to missing data can be well controlled for by the inclusion of the entire array of control variables, particularly the logged income-to-needs ratio and employment status. Specifically, we find that the selection model yields coefficients that are virtually identical to those from the model estimated without selection. Further, the multiple imputation model also generates results quite similar to those of the non-selection model. Both of these alternative models suggest that the magnitude of the selection effect is relatively small and does not alter the three-way relationship of interest - that is, how incomes have fared in the TANF era among poor, less-educated individuals.

\section{Difference-in-Differences Analysis}

To further support or challenge our results based on the previous analyses, we also adopt a difference-in-differences framework to our analysis. This approach, taken by many others before us, allows one to sort out the difference in influence that a particular policy or "treatment," in general - may have on a specific subgroup of the population.

In difference-in-differences analyses, the method is to compare one group that is suspected of being affected by a policy or "treatment" with one that is assumed to be affected only minimally, if at all. Thus, our strategy is first, to contrast the change over a one-year period in the logged income-to-needs ratios of single mother families who are poor at time 1 with the corresponding change in the ratios of such families who are relatively well- 
off at that time 1, all during the pre-welfare reform era. We choose an income level of more than three times the poverty threshold to define our group of those who are "well-off" and who are presumably affected little by welfare reform. Subsequently, we perform the same contrast, but during the TANF era. Thus, for each era, we have a difference in the change in logged income-to-needs ratios between two adjacent years between single mother families who are poor and those who are well-off. If the eras do not differ in how income dynamics operate, then we would expect similar differences in the two eras between the changes for the two income groups. This lack of effect would manifest itself in a zero "difference-indifferences." A non-zero difference-in-differences would imply that the eras do indeed differ with respect to how income change is generated from one year to the next for the two groups. By focusing exclusively on single mothers, we eliminate the possibility that our original difference-in-differences finding is confounded by a comparison of single-parent families with two-parent families.

In Table 3, we display the results of our difference-in-differences analysis. We compare the logged income-to-needs ratios of single mother families under the poverty threshold with those whose incomes exceed three times that threshold, for each of two time periods - 1988-1990, which represents the pre-welfare reform era and 1998-2000, which represents the TANF era. Again, the economic well-being of this more well-off group (i.e., greater than 300 percent of the poverty line) is assumed to be affected only minimally by the implementation of the TANF policy. Within each group - one under 100 percent of the poverty line and one over 300 percent - the difference observed represents a combination of both TANF and business cycle effects. However, when we compare changes in income and take the difference in the changes experienced by the two groups, we can isolate the effects of TANF from more general business cycle effects. 
First, let us examine all individuals, regardless of educational attainment. Looking at the logged income-to-needs ratios across time, we see that income decreased for those under the poverty line at time 1 (the logged ratio declined from -0.802 to -1.011 ). The corresponding change for individuals whose incomes were greater than 300 percent of the poverty line at time 1 actually was positive. The logged ratios increased by .024 , from 1.185 to 1.208. Because the difference-in-differences is significantly negative, we conclude that the TANF era had a substantially negative association with the economic well-being of poor people.

Next, we conduct a similar analysis for these two groups, broken down by educational attainment - those with and without a high school degree. The difference-in-differences results indicate that it is specifically less-educated poor people who have experienced TANF policy negatively. High school graduates who were initially poor seem to have been unaffected by the TANF policy. These difference-in-differences findings lend strong support to the conclusions drawn from our previous analyses. ${ }^{78}$

\section{Estimated Changes in Income-to-Needs Ratios in the TANF Environment}

\footnotetext{
${ }^{7}$ Earlier studies in labor economics found that there might be a decline in return for low-skilled workers in the early 1990's (Levy and Murnane, 1992, and Juhn et al. 1993). No study has documented whether that trend has continued into the late 1990's. Our estimation based on the method of difference-in-differences shows that there might be a continuation of that trend, but net of the trend for low-skilled workers, we still find a strong negative association between income and the TANF policy for parents achieving less than a high-school degree.

${ }^{8}$ March CPS family income includes, for all family members above age 15 , earned income from wage, farm, and non-farm self-employment, social security or railroad retirement, supplemental security income, public assistance payments, interest, dividends, veterans' payments or unemployment and workmen's compensation, pensions, alimony or child support, regular contributions from persons not living in the household, and other periodic income. ${ }^{8}$ However, it does not include the Earned Income Credit (EIC) or any in-kind assistance. We do not include the EIC in this study thus far so that we might isolate the pure relationship between TANF and income from an EIC effect. However, one might argue that we may still overestimate the strength of this TANF relationship because the EIC can create incentives to work (Lu and Bennett, 2001).

In difference-in-differences results not shown, we adopt a broader income measure suggested by the Census Bureau, which incorporates many additional sources of income and subtracts various taxes and expenses. Even using this alternative income measure, our findings are unequivocally supported.
} 
In order to facilitate the easy comprehension of the role of TANF in the economic wellbeing of children, we present the changes in income-to-needs ratios that are predicted by the multiple imputation model of Table $2 \mathrm{~b}$ for a variety of subgroups.

Figure 4 shows how TANF is associated with the family incomes of poor children across categories of the educational attainment of their parents. The displayed percentage changes in income-to-needs ratios are hypothetical estimates that assume mean values of all other variables. Implementation of TANF is associated with substantially lower income-to-needs ratios for children with parents who never graduated high school. TANF was associated with greater than a one-quarter (about 28 percent) decline in income between the two time periods for this group. In contrast, their much better educated counterparts - those who graduated college - appear actually to have improved their economic circumstances in the TANF era, with nearly a one-fifth (19 percent) increase in income.

\section{Discussion}

These results clearly demonstrate that the relationship between TANF and the family incomes of poor children has not been uniformly positive. Whether a poor child's family sees its income fall or rise in this recent era of welfare reform depends very much on the educational attainment of her parents. Our results based on four different estimation strategies - OLS with and without selection, modeling with multiple imputation, and difference-in-difference modeling - consistently support the hypothesis that TANF is associated with lower income-to-needs ratios among children with poor, less-educated parents. Specifically, data from the Current Population Survey indicate that poor parents who never earned a high school degree have been disadvantaged in the recent era of welfare reform. With the advent of universal welfare reform in the form of TANF, poor families with 
low levels of education have experienced significantly lower incomes as these programs have been implemented.

Our findings concerning the poorer outcomes among children in families whose parents have not completed high school are in contrast to results obtained by Moffitt (1999), who found no significant waiver effect on income among the least educated women. Our results also run counter to those by Schoeni and Blank (2000), who had found waivers were associated with increased income among this group of women, although they found no such effect for TANF (for all women). These studies, however, were based on cross-sectional analyses of the Current Population Survey. We would contend that the panel approach adopted in this study is better suited to picking up the true association between income and TANF, waivers, and the period prior to any welfare reform.

Six years have passed since PRWORA was enacted and several more since the implementation of many state waiver programs. As policy makers and scholars debate the law's reauthorization, it is critical to know who benefits from, and who is being hurt by, welfare reform. Our findings reveal a significant bifurcation of the relationship between TANF and the economic well-being of poor children. TANF may be deemed something of a triumph in public policy, but only in narrow terms. Children of relatively well-educated parents appear to have reaped benefits from the TANF program. However, it is the children of the least-educated poor parents who have experienced a significant decline in economic well-being due to the implementation of TANF. In the reauthorization debates, it is important that the federal government seek to reinforce its successes resulting from the TANF program and, at the same time, improve the welfare of those currently not benefiting from indeed, being hurt by - the new TANF rules and regulations. 
Table 1: Comparison of income-to-needs ratios for matched sample and matched plus imputed sample.

\begin{tabular}{|c|c|c|c|c|}
\hline & \multicolumn{2}{|c|}{ Matched Sample } & \multicolumn{2}{|c|}{ Matched plus Imputed Sample } \\
\hline & $\begin{array}{c}\text { Percent } \\
\text { Composition }\end{array}$ & Income-to-needs & $\begin{array}{c}\text { Percent } \\
\text { Composition }\end{array}$ & Income-to-needs \\
\hline White & 74 & 2.76 & 71 & 2.68 \\
\hline Black & 14 & 1.18 & 14 & 1.09 \\
\hline Hispanic & 7 & 1.23 & 10 & 1.14 \\
\hline Other & 5 & 2.14 & 5 & 2.06 \\
\hline Age of Parent 20 or less & 1 & 0.83 & 1 & 0.76 \\
\hline Age of Parent 21-30 & 14 & 1.32 & 17 & 1.26 \\
\hline Age of Parent 31 or more & 85 & 2.54 & 82 & 2.42 \\
\hline Rural & 22 & 1.87 & 21 & 1.79 \\
\hline Non Rural & 78 & 2.43 & 79 & 2.26 \\
\hline Both Parents & 78 & 2.85 & 77 & 2.74 \\
\hline Mother Only & 19 & 1.01 & 20 & 0.90 \\
\hline Father Only & 3 & 1.64 & 3 & 1.67 \\
\hline Parent Currently Married & 79 & 2.82 & 78 & 2.70 \\
\hline Parent Never Married & 7 & 0.72 & 8 & 0.66 \\
\hline Parent Div/Sep/Wid & 14 & 1.35 & 14 & 1.21 \\
\hline Parent Employed at $\mathrm{t} 1$ & 89 & 2.74 & 88 & 2.60 \\
\hline Parent Unemployed at t1 & 11 & 0.54 & 12 & 0.57 \\
\hline Under Poverty at t1 & 15 & 0.55 & 17 & 0.52 \\
\hline Above Poverty at t 1 & 85 & 2.94 & 83 & 2.87 \\
\hline Less than High School & 10 & 0.75 & 12 & 0.68 \\
\hline High School & 29 & 1.71 & 30 & 1.66 \\
\hline Some College & 28 & 2.38 & 28 & 2.32 \\
\hline At least College Degree & 32 & 4.12 & 30 & 4.09 \\
\hline Number of Observations & \multicolumn{2}{|c|}{150,046} & \multicolumn{2}{|c|}{$203,514(223,467)$} \\
\hline
\end{tabular}

Note:

Reported incomes-to-needs ratios are the exponential of the mean of the log (income-to-needs ratio). CPS sampling weights are applied. The sample size with valid income-to-needs ratios at time 2 after imputation is 203,514. By assuming MAR, the sample statistics based on multiple imputations are used to represent the full sample, 223,467 children. 


\section{TABLE 2A : The RELATIONSHIP BETWEen TANF AND INCOME-TO-NEEDS RATIOS OVER TIME (OLS W/ UNIMPUTED SAMPLE)}

\begin{tabular}{|c|c|c|c|c|c|c|c|c|}
\hline \multirow[b]{3}{*}{ Variables } & \multicolumn{8}{|c|}{ INCOME-TO-NEEDS RATIO AT TIME 2} \\
\hline & \multicolumn{2}{|c|}{$\begin{array}{c}\text { Model } 1 \\
\text { (w/out time dummies) }\end{array}$} & \multicolumn{2}{|c|}{$\begin{array}{c}\text { Model } 2 \\
\text { (w/time dummies) }\end{array}$} & \multicolumn{2}{|c|}{$\begin{array}{c}\text { Model } 3 \\
\text { (w/time dummies) }\end{array}$} & \multicolumn{2}{|c|}{$\begin{array}{c}\text { Model } 4 \\
\text { (w/time and state } \\
\text { dummies }+ \\
\text { interaction terms) }\end{array}$} \\
\hline & Coefficients & $\begin{array}{l}\text { Standard } \\
\text { Errors }\end{array}$ & Coefficients & $\begin{array}{l}\text { Standard } \\
\text { Errors }\end{array}$ & Coefficients & $\begin{array}{l}\text { Standard } \\
\text { Errors }\end{array}$ & Coefficients & $\begin{array}{l}\text { Standard } \\
\text { Errors }\end{array}$ \\
\hline Constant & $0.775^{*}$ & .004 & $0.825^{*}$ & .009 & $1.046^{*}$ & .008 & $0.417^{*}$ & .058 \\
\hline TANF & $0.076^{*}$ & .007 & 0.019 & .023 & 0.008 & .020 & -0.017 & .020 \\
\hline Poor at $\mathrm{t} 1$ & & & & & $-1.586^{*}$ & .014 & $-0.335^{*}$ & .025 \\
\hline TANF * Poor at $\mathrm{t} 1$ & & & & & $-0.129^{*}$ & .029 & -0.003 & .043 \\
\hline TANF * $<$ HS & & & & & & & 0.011 & .027 \\
\hline TANF * Some College & & & & & & & $0.042^{*}$ & .013 \\
\hline TANF $* \geq$ College & & & & & & & $0.058^{*}$ & .013 \\
\hline TANF * Poor * <HS & & & & & & & $-0.298^{*}$ & .069 \\
\hline TANF * Poor * Some College & & & & & & & -0.120 & .072 \\
\hline TANF * Poor $* \geq$ College & & & & & & & 0.119 & .114 \\
\hline Black & & & & & & & $-0.171^{*}$ & .011 \\
\hline Hispanic & & & & & & & $-0.188^{*}$ & .012 \\
\hline Other & & & & & & & $-0.163^{*}$ & .017 \\
\hline Age of Child & & & & & & & $0.008^{*}$ & .001 \\
\hline Age of Parent 21-30 & & & & & & & $-0.282^{*}$ & .048 \\
\hline Age of Parent 31 or more & & & & & & & $-0.205^{*}$ & .048 \\
\hline Non Rural & & & & & & & $0.114^{*}$ & .006 \\
\hline Mother Only & & & & & & & $-0.122^{*}$ & .056 \\
\hline Father Only & & & & & & & $-0.113^{*}$ & .057 \\
\hline Parent Never Married & & & & & & & -0.096 & .058 \\
\hline Parent Div/Sep/Wid & & & & & & & 0.014 & .057 \\
\hline Number of Children & & & & & & & $-0.175^{*}$ & .005 \\
\hline Family Size & & & & & & & $0.076^{*}$ & .004 \\
\hline Parent Employed at $\mathrm{t} 1$ & & & & & & & $0.535^{*}$ & .016 \\
\hline Log of Income-to-needs ratio at t1 & & & & & & & $0.303^{*}$ & .011 \\
\hline Unemployment Rate & & & & & & & $-0.015^{*}$ & .003 \\
\hline Less than High School & & & & & & & -0.189 & .017 \\
\hline Some College & & & & & & & $0.114^{*}$ & .008 \\
\hline At least College Degree & & & & & & & $0.350^{*}$ & .008 \\
\hline$<\mathrm{HS} *$ Poor at $\mathrm{t} 1$ & & & & & & & $0.163^{*}$ & .034 \\
\hline Some College * Poor at $\mathrm{t} 1$ & & & & & & & 0.061 & .037 \\
\hline$\geq$ College Degree * Poor at $\mathrm{t} 1$ & & & & & & & 0.153 & .074 \\
\hline Sample Size & 150,046 & & 150,046 & & 150,046 & & 150,046 & \\
\hline
\end{tabular}




\section{TABLE 2B: THE RELATIONSHIP BETWEEN TANF AND INCOME-TO-NEEDS RATIOS OVER TIME (OLS W/IMPUTED SAMPLE AND SELECTION CORRECTION MODEL)}

\begin{tabular}{|c|c|c|c|c|}
\hline \multirow[b]{3}{*}{ Variables } & \multicolumn{4}{|c|}{$\begin{array}{c}\text { INCOME-TO-NEEDS RATIO AT TIME } 2 \\
\text { Model } 4 \\
\text { (w/time and state dummies + interaction terms) }\end{array}$} \\
\hline & \multicolumn{2}{|c|}{ OLS with imputed sample } & \multicolumn{2}{|c|}{ Selection Correction Model } \\
\hline & Coefficients & $\begin{array}{l}\text { Standard } \\
\text { Errors }\end{array}$ & Coefficients & $\begin{array}{l}\text { Standard } \\
\text { Errors }\end{array}$ \\
\hline Constant & $0.592^{*}$ & .058 & $0.409^{*}$ & .057 \\
\hline TANF & -0.021 & .020 & -0.017 & .020 \\
\hline Poor at $\mathrm{t} 1$ & $-0.435^{*}$ & .025 & $-0.335^{*}$ & .025 \\
\hline TANF * Poor at $\mathrm{t} 1$ & 0.011 & .043 & -0.003 & .043 \\
\hline TANF $*<$ HS & -0.010 & .027 & 0.011 & .027 \\
\hline TANF * Some College & $0.036^{*}$ & .013 & $0.042^{*}$ & .013 \\
\hline TANF ${ }^{*} \geq$ College & $0.046^{*}$ & .013 & $0.058^{*}$ & .013 \\
\hline TANF * Poor * $<$ HS & $-0.302^{*}$ & .069 & $-0.298^{*}$ & .069 \\
\hline TANF * Poor * Some College & -0.150 & .072 & -0.120 & .072 \\
\hline TANF * Poor * $\geq$ College & 0.138 & .114 & 0.120 & .113 \\
\hline Black & $-0.179^{*}$ & .011 & $-0.171^{*}$ & .011 \\
\hline Hispanic & $-0.187^{*}$ & .012 & $-0.191^{*}$ & .012 \\
\hline Other & $-0.127^{*}$ & .017 & $-0.163^{*}$ & .017 \\
\hline Age of Child & $0.008^{*}$ & .001 & $0.008^{*}$ & .001 \\
\hline Age of Parent 21-30 & $-0.252^{*}$ & .048 & $-0.281^{*}$ & .048 \\
\hline Age of Parent $\mathbf{3 1}$ or more & $-0.183^{*}$ & .048 & $-0.203^{*}$ & .048 \\
\hline Non Rural & $0.109^{*}$ & .006 & $0.114^{*}$ & .006 \\
\hline Mother Only & $-0.153^{*}$ & .056 & $-0.123^{*}$ & .056 \\
\hline Father Only & $-0.118^{*}$ & .057 & $-0.115^{*}$ & .057 \\
\hline Parent Never Married & -0.099 & .058 & -0.096 & .058 \\
\hline Parent Div/Sep/Wid & -0.007 & .057 & 0.014 & .057 \\
\hline Number of Children & $-0.171^{*}$ & .005 & $-0.175^{*}$ & .005 \\
\hline Family Size & $0.070^{*}$ & .004 & $0.076^{*}$ & .004 \\
\hline Parent Employed at $\mathrm{t} 1$ & $0.389^{*}$ & .016 & $0.535^{*}$ & .016 \\
\hline Log of Income-to-needs ratio at $\mathrm{t} 1$ & $0.253^{*}$ & .011 & $0.303^{*}$ & .011 \\
\hline Unemployment Rate & $-0.015^{*}$ & .003 & $-0.015^{*}$ & .003 \\
\hline Less than High School & $-0.202^{*}$ & .017 & $-0.189^{*}$ & .017 \\
\hline Some College & $0.129^{*}$ & .008 & $0.114^{*}$ & .008 \\
\hline At least College Degree & $0.388^{*}$ & .008 & $0.351^{*}$ & .008 \\
\hline$<$ HS * Poor at $\mathrm{t} 1$ & $0.106^{*}$ & .034 & $0.164^{*}$ & .034 \\
\hline Some College * Poor at t 1 & 0.028 & .037 & 0.061 & .037 \\
\hline$\geq$ College Degree * Poor at $\mathrm{t} 1$ & 0.043 & .074 & $0.153^{*}$ & .074 \\
\hline Lambda & & & $0.008^{*}$ & .002 \\
\hline Sample Size & 223,467 & & 223,467 & \\
\hline
\end{tabular}

Note: * Statistically significant at .05 level 
TABLE 3: A DIFFERENCE-IN-DIFFERENCES APPROACH TO ASSESS THE ASSOCIATION BETWEEN THE TANF ERA AND LOGGED INCOME-TO-NEEDS RATIOS, BY EDUCATION, FOR SINGLE MOTHER FAMILIES.

\begin{tabular}{lcccccc} 
& \multicolumn{2}{c}{$1988-1990$} & \multicolumn{2}{c}{$1998-2000$} & \multicolumn{2}{c}{ Difference } \\
& Mean & S.D. & Mean & S.D. & Mean & S.D. \\
$\begin{array}{l}<100 \% \text { of Poverty Line } \\
\text { at time 1 }\end{array}$ & & & & & & \\
All & -0.802 & 0.033 & -1.011 & 0.063 & -0.209 & 0.075 \\
Less than HS degree & -0.908 & 0.056 & -1.573 & 0.123 & -0.665 & 0.134 \\
At least HS degree & -0.694 & 0.040 & -0.689 & 0.059 & 0.005 & 0.074 \\
& & & & & & \\
$>300 \%$ of Poverty Line & & & & & & \\
$\quad$ at time 1 & 1.185 & 0.037 & 1.208 & 0.030 & 0.024 & 0.049 \\
All & 1.126 & 0.080 & 0.899 & 0.089 & -0.227 & 0.121 \\
Less than HS degree & 1.189 & 0.039 & 1.219 & 0.031 & 0.030 & 0.051 \\
At least HS degree & & & & & &
\end{tabular}

Difference Between Income Groups $<100 \%$ vs. $>300 \%$ of Poverty Line

\begin{tabular}{|c|c|c|c|c|c|c|}
\hline & \multicolumn{2}{|c|}{$1988-1990$} & \multicolumn{2}{|c|}{$1998-2000$} & \multicolumn{2}{|c|}{$\begin{array}{l}\text { Diff in Diff } \\
\text { (Policy Effect) }\end{array}$} \\
\hline & Mean & S.D. & Mean & S.D. & Mean & S.D. \\
\hline All & -1.987 & 0.053 & -2.220 & 0.242 & -0.233 & 0.092 \\
\hline Less than HS degree & -2.035 & 0.099 & -2.472 & 0.148 & -0.437 & 0.175 \\
\hline At least HS degree & -1.883 & 0.053 & -1.908 & 0.074 & -0.025 & 0.091 \\
\hline \multicolumn{5}{|c|}{$\begin{array}{l}\text { Diff in Diff in Diff (Less than HS degree } \\
\text { vs. at least HS degree ) }\end{array}$} & -0.412 & 0.185 \\
\hline
\end{tabular}




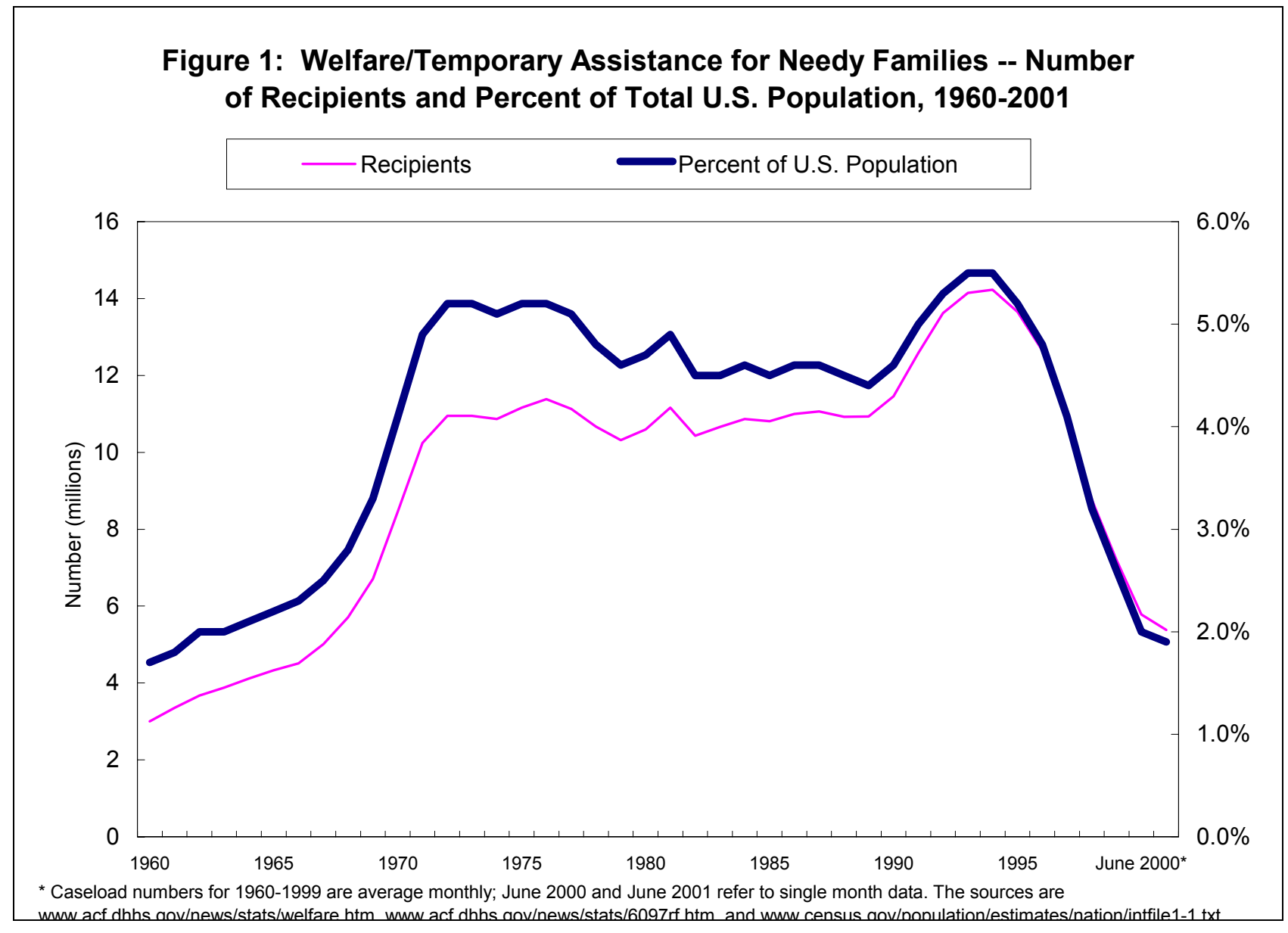


Figure 2: Trends in Child Poverty and Welfare Caseload

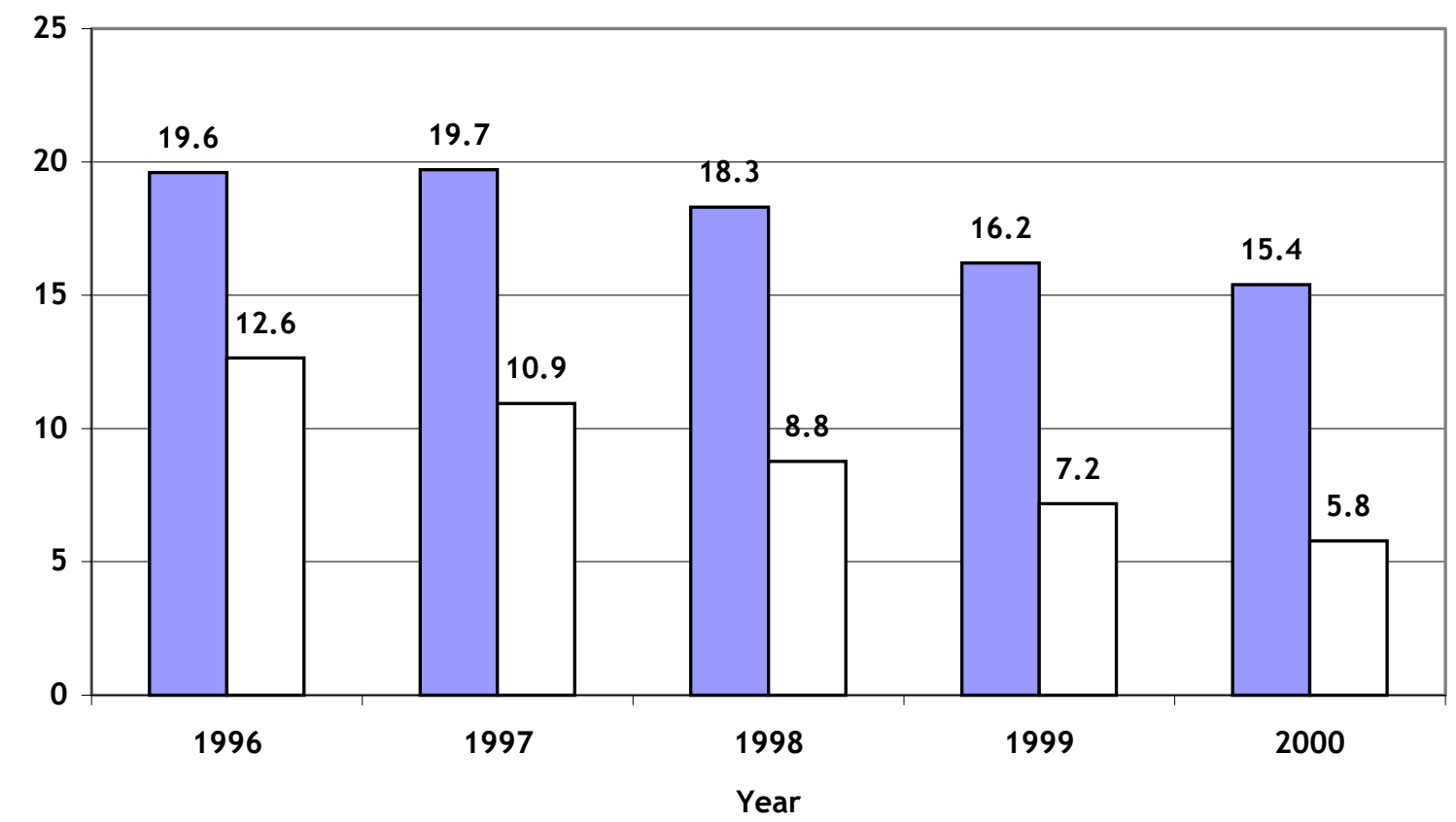

$\square$ Percent Children in Poverty $\square$ Welfare Recipients (in millions) Note: Poverty rates obtained by authors from the March Current Population Surveys 
Figure 3a: t2 Income-to-needs ratio of children poor at t1

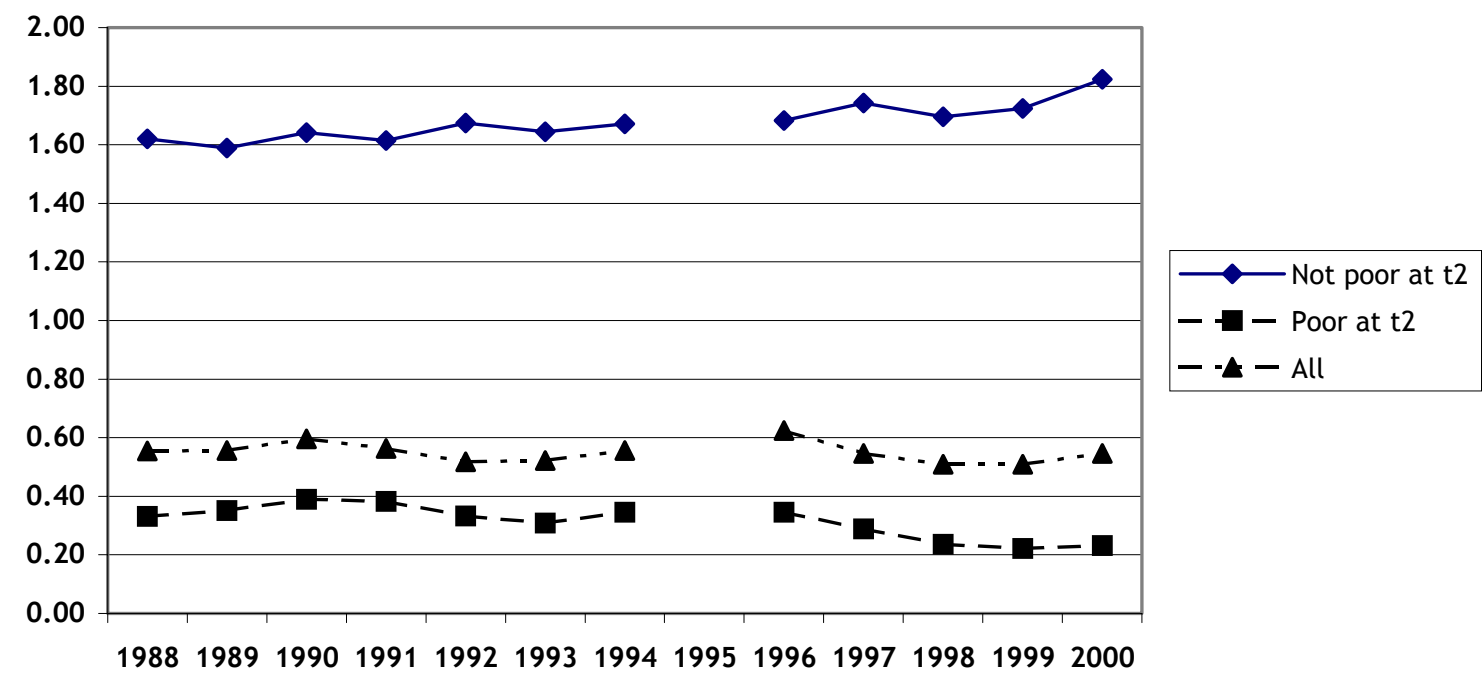


Figure 3b: t2 Income-to-needs ratio of children not poor at t2 but poor at $\mathrm{t} 1$

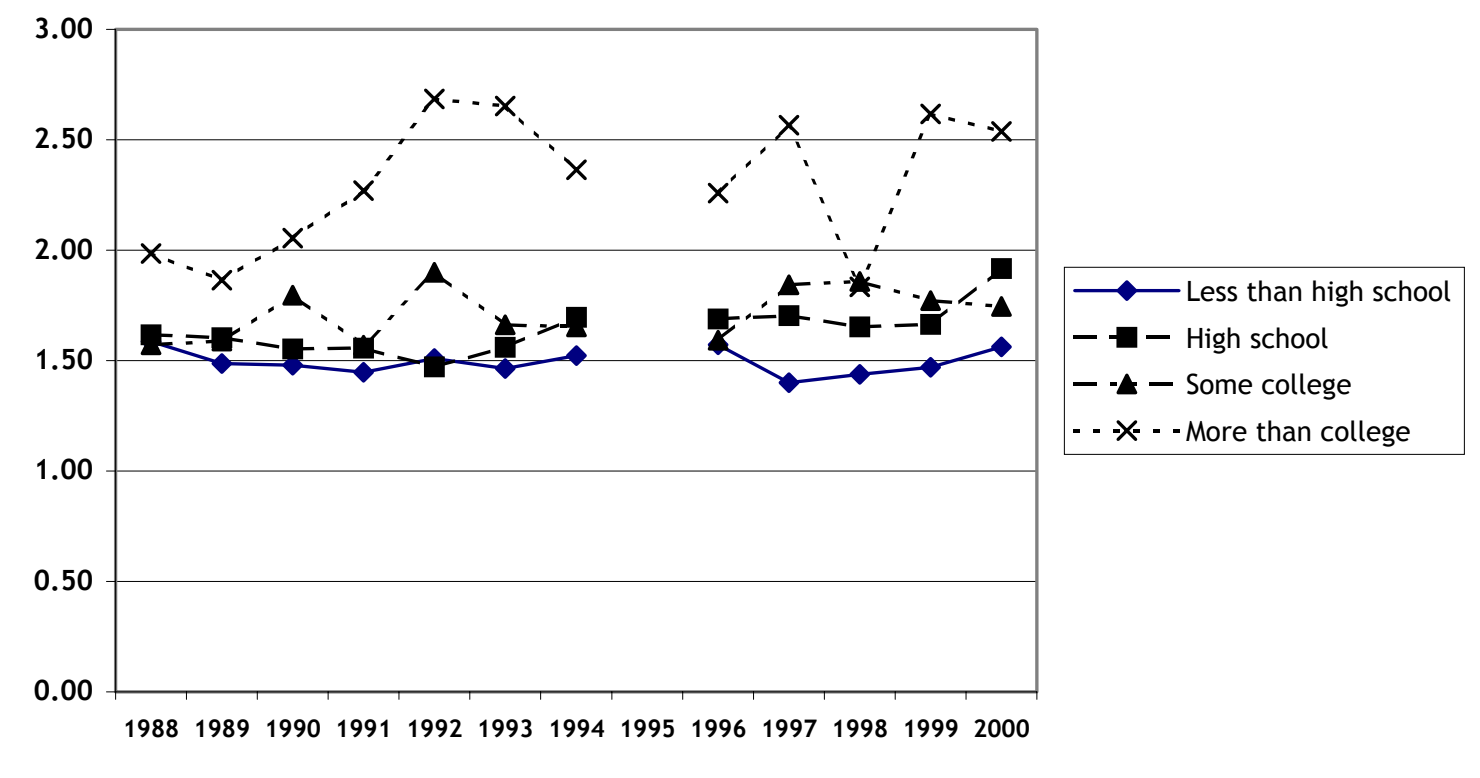




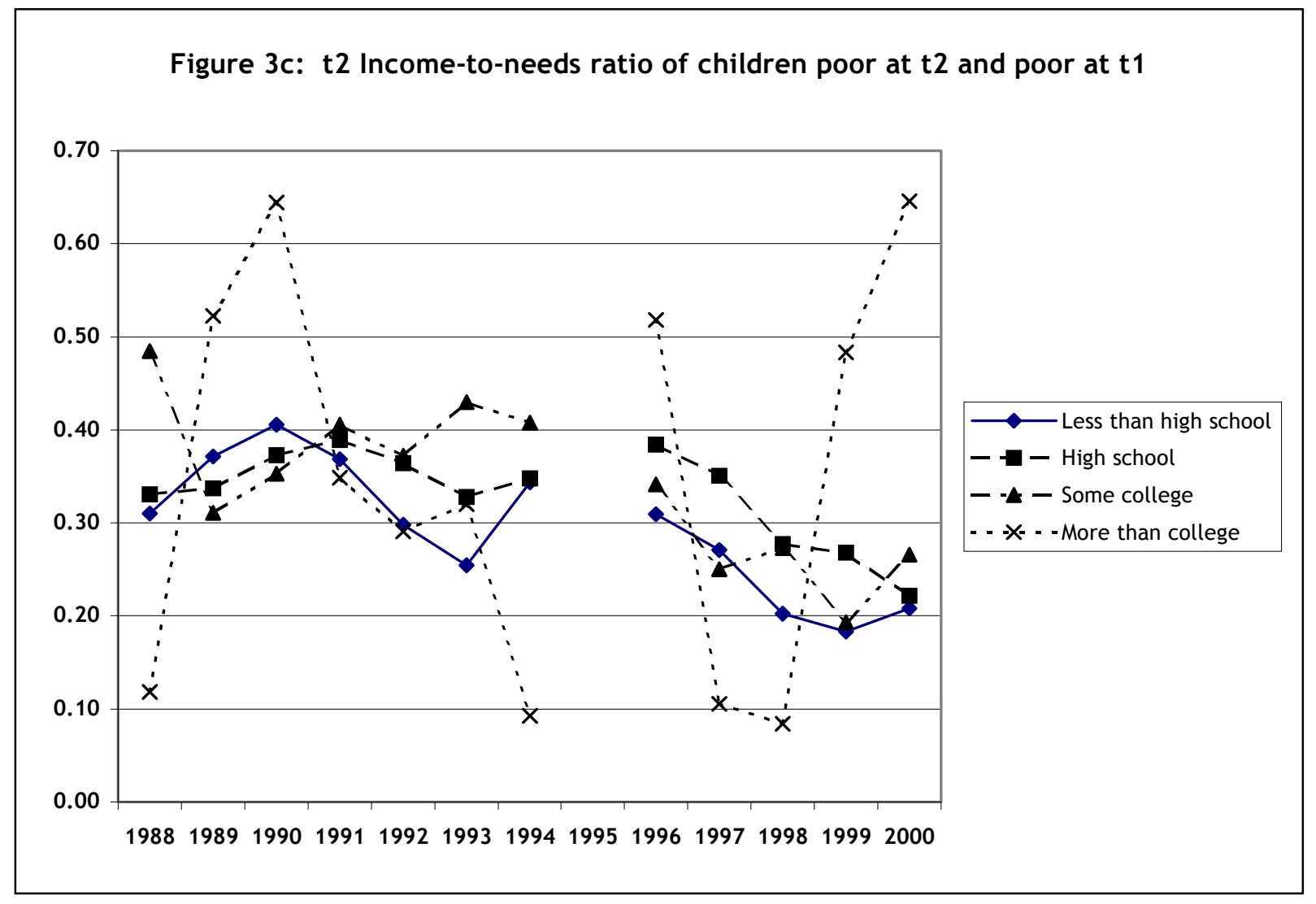


Figure 4: Percent Change in Income-to-Needs Ratio at Time 2 for Those

Poor at Time 1, by Education,

TANF Era vs. Period Prior to Waivers

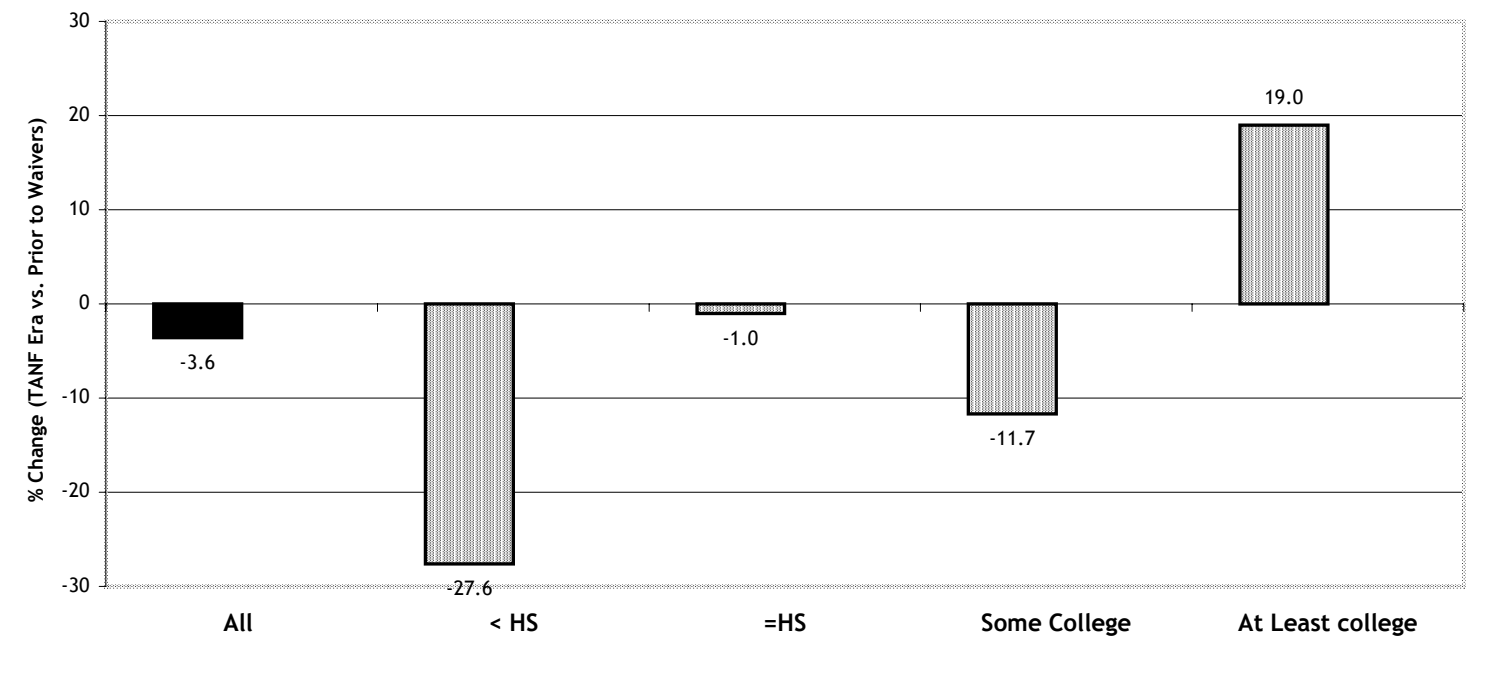


Table A1: Dates of implementation of waivers and TANF, by state.

\begin{tabular}{|c|c|c|c|c|c|}
\hline STATE & Waiver & TANF & STATE & Waiver & TANF \\
\hline $\mathrm{AL}$ & --- & $11 / 15 / 96$ & $\mathrm{MO}$ & $6 / 1 / 95$ & $12 / 1 / 96$ \\
\hline AK & -- & 7/1/97 & $\mathrm{NE}$ & $10 / 1 / 95$ & $12 / 1 / 96$ \\
\hline$A Z$ & $11 / 1 / 95$ & $10 / 1 / 96$ & NV & -- & $12 / 3 / 96$ \\
\hline$A R$ & 7/1/94 & 7/1/97 & $\mathrm{NH}$ & -.- & $10 / 1 / 96$ \\
\hline $\mathrm{CA}$ & $12 / 1 / 92$ & $1 / 1 / 98$ & NJ & $10 / 1 / 92$ & 7/1/97 \\
\hline $\mathrm{CO}$ & -- & $7 / 1 / 97$ & NM & - & $7 / 1 / 97$ \\
\hline CT & $1 / 1 / 96$ & $10 / 1 / 96$ & NY & -- & $11 / 1 / 97$ \\
\hline $\mathrm{DE}$ & $10 / 1 / 95$ & $3 / 10 / 97$ & NC & $7 / 1 / 96$ & $1 / 1 / 97$ \\
\hline $\mathrm{DC}$ & -.- & $3 / 1 / 97$ & ND & $7 / 1 / 96$ & 7/1/97 \\
\hline $\mathrm{FL}$ & $2 / 1 / 94$ & $10 / 1 / 96$ & $\mathrm{OH}$ & $7 / 1 / 96$ & $10 / 1 / 96$ \\
\hline $\mathrm{GA}$ & $1 / 1 / 94$ & $1 / 1 / 97$ & OK & -- & $10 / 1 / 96$ \\
\hline $\mathrm{HI}$ & $2 / 1 / 97$ & $7 / 1 / 97$ & OR & $2 / 1 / 93$ & $10 / 1 / 96$ \\
\hline ID & --- & $7 / 1 / 97$ & PA & -.- & $3 / 3 / 97$ \\
\hline IL & $11 / 23 / 93$ & $7 / 1 / 97$ & RI & -- & $5 / 1 / 97$ \\
\hline IN & 5/1/95 & $10 / 1 / 96$ & $\mathrm{SC}$ & --- & $10 / 12 / 96$ \\
\hline IA & $10 / 1 / 93$ & $1 / 1 / 97$ & SD & $6 / 1 / 94$ & $12 / 1 / 96$ \\
\hline KS & -.- & $10 / 1 / 96$ & TN & $9 / 1 / 96$ & $10 / 1 / 96$ \\
\hline KY & --- & $10 / 18 / 96$ & TX & $6 / 1 / 96$ & $11 / 5 / 96$ \\
\hline LA & -- & $1 / 1 / 97$ & UT & $1 / 1 / 93$ & $10 / 1 / 96$ \\
\hline ME & --- & $11 / 1 / 96$ & VT & $7 / 1 / 94$ & $9 / 20 / 96$ \\
\hline MD & $3 / 1 / 96$ & $12 / 9 / 96$ & VA & $7 / 1 / 95$ & $2 / 1 / 97$ \\
\hline MA & $11 / 1 / 95$ & $9 / 30 / 96$ & WA & $1 / 1 / 96$ & $1 / 10 / 97$ \\
\hline MI & $10 / 1 / 92$ & $9 / 30 / 96$ & WV & $2 / 1 / 96$ & $1 / 11 / 97$ \\
\hline MN & 4/1/94 & $7 / 1 / 97$ & WI & $1 / 1 / 96$ & $9 / 1 / 97$ \\
\hline MS & $10 / 1 / 95$ & $7 / 1 / 97$ & WY & -.- & $1 / 1 / 97$ \\
\hline
\end{tabular}

Sources:

State Implementation of Major Changes to Welfare Policies, 1992-1998. (Table A)

Human Services Policy (HSP), Assistant Secretary for Planning and Evaluation (ASPE), US Department of Health and

Human Services (HHS) http://aspe.hhs.gov/search/hsp/Waiver-Policies99/W1tim_limt.htm

Note:.$--=$ no state waiver 


\section{Appendix: Multiple Imputation Method}

The model used to produce multiple imputation results is similar to our final model. In this final model, however, we collapsed age groups, the number of dependents, time one poverty ratios, and family sizes in order to eliminate empty cells, which would not allow the imputation of data, and therefore to generate more imputed data. The results from imputation with collapsed categories are consistent with those obtained without collapsing any variables.

Given the dimensions controlled for in the multiple imputation procedure, the imputed data can be treated as data without missing data problems. By doing so, we assume that the missing data were generated either "completely at random" (MCAR) or "at random" (MAR) (Rubin 1987, Schafer 1997). In our analyses, we produced five imputed complete data sets $(M=5)$, which is suggested by previous studies to be sufficient to obtain valid inferences (Schafer 1997, Schafer and Olsen 1998). In each of the imputed data sets, using a bootstrap procedure, $\mathrm{n}_{\text {observed }}$ cases (i.e., the number of cases with observed data) were randomly drawn with replacement from each cell defined by the dimensions implied by our final model. The bootstrap sample drawn from the observed cases in each cell is of the same size as the original number of cases observed in the cell. In each of the $M$ data augmentation procedures, a sample of $\mathrm{n}_{\text {missing }}$ cases (i.e., the number of cases with missing data) are drawn from the bootstrap sample associated with each cell. The same procedure was repeated five times to produce five imputed complete data samples. Following Rubin (1987), we take the average of estimates from all five samples to produce the mean value $\bar{b}$ of parameters of interests. The standard error of an estimate $\bar{b}$ based on multiple imputation is the following (Allison, 2000):

$$
\operatorname{STDERR}_{\bar{b}}=\sqrt{\frac{1}{M} \sum_{k} S_{k}^{2}+\left(1+\frac{1}{M}\right)\left(\frac{1}{M-1}\right) \sum_{k}\left(b_{k}-\bar{b}\right)^{2}}
$$


where $M$ is $5, k$ is the $k^{\text {th }}$ sample of the five imputed samples, and $S_{k}^{2}$ and $b_{k}$ are the observed standard error and parameter estimated in the $\mathrm{k}^{\text {th }}$ sample. 


\section{References}

Allison, Paul D. 2000. "Multiple Imputation for Missing Data: A Cautionary Tale." Sociological Methods \& Research 28(3):301-309.

Blank, Rebecca. 2002. "Evaluating Welfare Reform in the United States." Working Paper 8983, Cambridge, MA: National Bureau of Economic Research.

Bumpass, Larry and Hsien-Hen Lu. 2000. "Trends in Cohabitation and Implications for Children's Family Contexts in the United States." Population Studies 54:29-41.

Cancian, Maria, Robert Haveman, Thomas Kaplan, and Barbara Wolfe. 1999. "Post-Exit Earnings and Benefit Receipt among Those Who Left AFDC in Wisconsin." Special Report No. 75, Madison, WI: Institute for Research on Poverty.

Cancian, Maria, Robert Haveman, Daniel R. Meyer, and Barbara Wolfe. 2000. "Before and After TANF: The Economic Well-Being of Women Leaving Welfare." Special Report No. 77, Madison, WI: Institute for Research on Poverty.

Connolly, Laura S. 2000. "The Effect of Welfare Reform on the Incomes and Earnings of Lowincome Families: Evidence from the Current Population Survey." Paper prepared for "Rural Dimensions of Welfare Reform: A Research Conference on Poverty, Welfare, and Food Assistance," sponsored by the Joint Center for Poverty Research, Washington, DC, 4-5 May 2000.

Ellwood, David T. 2001. "The Impact of the Earned Income Tax Credit and Social Policy Reforms on Work, Marriage, and Living Arrangements." National Tax Journal 53(4), Part 2:1063-1105.

Garrett, Bowen, and John Holahan. 2000. "Health Insurance Coverage after Welfare." Health Affairs 19(1):175-184.

Heckman, James J. 1979. "Sample Selection Bias as a Specification Error." Econometrica 46:931-961.

Huber, P. J. 1967. "The Behavior of Maximum Likelihood Estimates under Non-Standard Conditions." In Proceedings of the Fifth Berkeley Symposium on Mathematical Statistics and Probability. Berkeley, CA: University of California Press, 1:221-233.

Juhn, Chinhui, Kevin M. Murphy, and Brooks Pierce. 1993. "Wage Inequality and the Rise in Returns to Skill." Journal of Political Economy 101(3):410-442.

Katz, Arnold, Klaus Teuter, and Philip Sidel. 1984. "Comparison of Alternative Ways of Deriving Panel Data from the Annual Demographic Files of the Current Population Survey." Review of Public Data Use 12:35-44.

Land, K. C., and P. L. Mccall. 1993. "Estimating the Effect of Nonignorable Nonresponse in Sample Surveys." Sociological Methods \& Research 21:291-316. 
Levy, Frank, and Richard J. Murnane. 1992. "U.S. Earnings Levels and Earnings Inequality: A Review of Recent Trends and Proposed Explanations." Journal of Economic Literature 30(Sep.):1333-1381.

Lichter, Daniel T., and Leif Jensen. 2000. "Rural America in Transition: Poverty and Welfare at the Turn of the $21^{\text {st }}$ Century." Unpublished manuscript.

Little, R.J.A., and D. B. Rubin. 1987. Statistical Analysis with Missing Data. New York: J. Wiley \& Sons.

Loprest, Pamela. 1999. "Families Who Left Welfare: Who Are They and How Are They Doing?” Discussion Paper 99-02, Washington, DC: Urban Institute.

Lu, Hsien-Hen, and Neil G. Bennett. 2001. "Impact of the Earned Income Tax Credit on Poverty among Children in Single-Parent Families." Paper presented at the annual meeting of the American Sociological Association in Los Angeles, CA.

Madrian, Brigitte C. and Lars John Lefgren. 1999. "A Note on Longitudinally Matching Current Population Survey (CPS) Respondents." Technical Working Paper 247, National Bureau of Economic Research, Cambridge, MA.

Mander, Adrian, and David Clayton. 1999. "Hotdeck Imputation." Stata Technical Bulletin 51:32-34.

Meyer, Bruce. 1995. "Natural and Quasi-experiments in Economics." Journal of Business and Economic Statistics 13:151-161.

Moffitt, Robert A. 1999. "The Effect of Pre-PRWORA Waivers on AFDC Caseloads and Female Earnings, Income, and Labor Force Behavior." In Economic Conditions and Welfare Reform, S. H. Danziger, ed., Kalamazoo, MI: W. E. Upjohn Institute for Employment Research.

Moffitt, Robert A., and Michele Ver Ploeg, editors. 2001. Evaluating Welfare Reform in an Era of Transition, Panel on Data and Methods for Measuring the Effects of Changes in Social Welfare Programs, Committee on National Statistics, National Research Council, Washington, DC: National Academy Press.

Nawata, Kazumitsu, and Nobuko Nagase. 1996. "Estimation of Sample Selection Bias Models." Econometric Reviews 15(4):387-400.

Peracchi, Franco, and Finis Welch. 1995. "How Representative are Matched Cross-Sections? Evidence from the Current Population Survey." Journal of Econometrics 68(1):153-179.

Primus, Wendell. 2001. "Testimony before the House Budget Committee." Marach 7. Available at http://www.house.gov/budget_democrats/hearings/yr2001/primusstmnt.pdf.

Rubin, Donald B. 1977. "Formalizing Subjective Notions about the Effect of Nonrespondents in Sample Surveys." Journal of the American Statistical Association 72(395):538-543.

Rubin, D.B. 1987. Multiple Imputation for Nonresponse in Surveys. New York: J. Wiley \& Sons. 
Rubin, D.B. 1996. "Multiple Imputation after 18+ Years (with discussion)." Journal of the American Statistical Association 91:473-489.

Schafer, Joseph L. 1997. Analysis of Incomplete Multivariate Data. New York: Chapman \& Hall.

Schafer, Joseph L., and Maren K. Olsen. 1998. "Multiple Imputation for Multivariate Missingdata Problems: A Data Analyst's Perspective." Mimeo, The Pennsylvania State University.

Schoeni, Robert F., and Rebecca M. Blank. 2000. "What Has Welfare Reform Accomplished? Impacts on Welfare Participation, Employment, Income, Poverty, and Family Structure." Working Paper 7627, National Bureau of Economic Research, Cambridge, MA.

Welch, Finis. 1993. "dm11 Matching the Current Population Surveys." Stata Technical Bulletin 12:34-40.

White, H. 1980. "A Heteroskedasticity-consistent Covariance Matrix Estimator and a Direct Test for Heteroskedasticity." Econometrica 48:817-830.

White, H. 1982. "Maximum Likelihood Estimation of Misspecfied Models." Econometrica 50:1-25.

Winship, Christopher, and Stephen L. Morgan. 1999. "The Estimation of Causal Effects from Observational Data." Annual Review of Sociology 25:659-706. 